УДК 784

DOI https://doi.org/10.24919/2308-4863/34-2-5

\author{
Валентина ЗЕЛІНКА, \\ orcid.org/0000-0002-8134-992X \\ заслужений працівник культури України, \\ викладач кафедри мистецьких дисииплін \\ Ужгородського інституту культури і мистеитв \\ (Ужггород, Україна)v.zelinka6493-5@unesp.co.uk \\ Степан ГІГА, \\ orcid.org/0000-0001-6961-2353 \\ народний артист Украӥни, \\ викладач кафедри мистещьких дисииплін \\ Ужсгородського інституту культури і мистеитв \\ (Ужсгород, Україна) hiha_step@national-univesity.info \\ Мар'яна МАТЕЙКО, \\ orcid.org/0000-0003-4929-8189 \\ викладач кафедри мистещьких дисциплін \\ Ужсгородського інституту культури і мистеитв \\ (Ужггород, Україна) ma.mateiko@kpi.com.de
}

\title{
РОЗВИТОК УКРАЇНСЬКОЇ ВОКАЛЬНОЇ ШКОЛИ НА СУЧАСНОМУ ЕТАПІ
}

У иьому науковому дослідженні розглядаються питання розвитку української вокальної школи на сучасному етапі формування національної культури. Украӥнська вокальна школа має глибокі традииії, початок формування яких уходить корінням у сиву давнину історії украӥнської нації. Мистецтвво украӥнського вокалу знане у всьому світі, тому розуміння послідовності розвитку української вокальної школи на сучасному етапі формування культурних традицій украӥнського народу є вельми важливим з точки зору надання оцінки вкладу окремих діячів національної культури Украйни у поступове спрямування иуього процесу. Наявність глибокого коріння традицій украӥнського співу на тлі реалій сьогоднішнього дня зумовлює важливість вивчення та розуміння широкого розмаїття аспектів української пісенної культури та ії справжнього місия на сучасному етапі розвитку української культури та суспільства. Актуальність заявленої тематики дослідження зумовлюсться значним внеском украӥнської вокальної культури у світову пісенну культуру та необхідністю якісного вивчення иього явища, надання йому об'єктивної оиінки. Методологія изього наукового дослідження має у своїй основі аналітичний підхід до розгляду питань, які було винесено у його заголовок. Якісний аналіз розмайття факторів, щцо становлять основу розвитку украӥнської вокальної школи, сприяє належному розкриттю тематики дослідження та формуванню остаточних висновків за його результатами. Головними результатами иьього наукового дослідження слід вважати визначення характерних ознак украӥнської школи оперного співу та чинників, за якими нині сформувався авторитет представників начіональної школи у різних куточках Земної кулі. Перспективи подальших наукових досліджень у визначеному напрямі зумовлюються необхідністю вивчення культури свого народу загалом і його пісенної і мовної культур та спадщини зокрема. Прикладна иінність иієї наукової роботи полягає у визначенні головних чинників розвитку української пісенності та можливості застосування надалі подібних результатів наукової роботи задля формування належного фундаменту щзодо визначення головних напрямів подальшого розвитку культури співу в Україні зокрема та загальнонаціональної культури загалом.

Ключові слова: культурна спадщина, украӥнська пісенність, пісенні традиції, музична інтонація. 


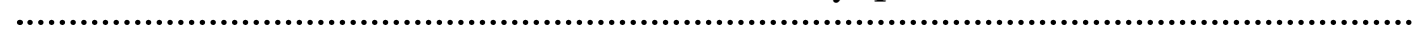

Valentyna ZELINKA,

orcid.org/0000-0002-8134-992X

Honored Worker of Ukraine Culture,

Senior Lecturer at the Department of Artistic Disciplines

Uzhhorod Institute of Culture and Arts

(Uzhhorod,Ukraine)v.zelinka6493-5@unesp.co.uk

\author{
Stepan HIHA, \\ orcid.org/0000-0001-6961-2353 \\ People's Artist of Ukraine, \\ Senior Lecturer at the Department of Artistic Disciplines \\ Uzhhorod Institute of Culture and Arts \\ (Uzhhorod,Ukraine)hiha_step@national-univesity.info
}

Mariana MATEIKO,

orcid.org/0000-0003-4929-8189

Senior Lecturer at the Department of Artistic Disciplines

Uzhhorod Institute of Culture and Arts

(Uzhhorod, Ukraine) ma.mateiko@kpi.com.de

\title{
DEVELOPMENT OF THE UKRAINIAN VOCAL SCHOOL AT THE PRESENT STAGE
}

\begin{abstract}
This study investigates the development of the Ukrainian vocal school at the present stage of development of national culture. The Ukrainian vocal school has deep traditions, the beginning of the development of which is rooted in the antiquity of the history of the Ukrainian nation. The art of Ukrainian vocal is known all over the world, and therefore understanding the sequence of development of the Ukrainian vocal school at the present stage of development of cultural traditions of the Ukrainian people is very important in terms of evaluating the contribution of individual national cultural figures in Ukraine. The presence of deep roots in the traditions of Ukrainian singing against the background of modern realities allows to investigate and understand the wide variety of aspects of Ukrainian song culture and its true place at the present stage of development of Ukrainian culture and society. The relevance of the stated subject is conditioned by the significant contribution of Ukrainian vocal culture to world song culture and the need for quality study of this phenomenon and its objective evaluation. The methodology of this study is based on an analytical approach to the subject matter. Qualitative analysis of the variety of factors that form the basis for the development of the Ukrainian vocal school contributes to the proper coverage of the subject under study and the development of final conclusions according to the study results. The main results of this study include the identification of the features of the Ukrainian school of opera singing and the factors that have developed the authority of the representatives of the national school in different parts of the globe. Prospects for further research are conditioned by the need to study the culture of its people in general, and its song and language cultures and heritage in particular. The applied value of this study is to determine the main factors in the development of Ukrainian song and the possibility of further application of similar results of scientific article to establish a proper foundation for determining the main directions of further development of singing culture in Ukraine in particular and national culture in general.
\end{abstract}

Key words: cultural heritage, Ukrainian song, song traditions, musical intonation.

Постановка проблеми. Пісенна культура будь-якої країни тісно пов'язана 3 її загальною історією та реаліями сьогодення. Біля витоків пісенно-фольклорних традицій будь-якого етносу лежить тісний зв'язок слова та співу, з'єднаних нерозривністю смислового інтонування. У ході вокального розвитку людства визрівали звукові та магічні формули й трудові приспіви, ритмові та інтонаційні обороти та лад-інтонаційні пласти фольклору. Синтетичний характер вокального мистецтва вимагає не тільки музикознавчого, а й філологічного вивчення. Головним аспектом вивчення вокальної спадщини будь-якого етносу $€$ та має бути визнання унікальності його мовної фонетики, генетичного взаємозв'язку між мовною та музично-мовною інтонацією. Саме звучання мови значною мірою допомагає виявити художню самобутність вокальної музики, сприяє усвідомленню особливостей співочих традицій та індивідуальних стилів (Ковбасюк, 2016: 78).

Тому слід вважати, що розвиток української вокальної школи варто розглядати невід'ємно від контексту формування багатовікової культури українського народу, чому активно сприяє діяльність багатьох діячів національної пісенної культури та культури взагалі. Адже формування національних пісенних традицій $\epsilon$ неможливим без якісного усвідомлення факту наявності тіс- 
них взаємозв'язків між українською пісенною культурою та культурою українського мовлення, a також багатьма іншими напрямами розвитку культурних тенденцій на всьому протязі розвитку історії української державності. Стосовно мовного аспекту формування та розвитку української пісенної спадщини та іï взаємозв'язку із розвитком української мови загалом варто відзначити, що звукові форми функціонування «магічного» складника української мови сприяли виділенню слова, смислова цінність якого представляла перш за все магічне, а вже потім поетичне наповнення (Ковбасюк, 2016: 79).

Сучасний виконавець вокальних творів, що становлять основу пісенного репертуару виконавця народної музики, повинен бути різнобічно освіченою людиною, людиною музично й художньо грамотною, такою, що добре розбирається в проблемах мистецтва, знає і глибоко розуміє фольклорні традиції та процеси розвитку народної творчості (Щербинина, 2013: 163). Натепер стан української системи освіти у сфері вивчення народно-співочого мистецтва можна вважати дуже важким 3 огляду на проблеми сучасного українського суспільства та використовувані методики щодо їх розв'язання. Але з огляду на різнобарвність розвитку української пісенної культури варто зазначити, що українська вокальна школа на сучасному етапі розвитку національного суспільства має вельми високий ступінь розвитку, що підтверджує iii авторитет у пісенному світі. Це дозволяє віддати належну шану історії розвитку української пісні та 3 оптимізмом дивитися у майбутнє.

Аналіз досліджень. Загальні питання розвитку української вокальної школи на сучасному етапі розглядаються у наукових дослідженнях А. М. Ковбасюк (2016), С. В. Щербініної (2013), Н. В. Муттер (2017), Е. М. Мелякиної (2010) та багатьох інших авторів. У своїх дослідженнях зазначені автори наголошують на головних закономірностях, що мають місце на різних стадіях розвитку українського співочого мистецтва, а також виявляють широке розмаїття факторів, що активно впливають на чинники розвитку української вокальної школи у контексті сьогоденних культурних явищ та проблем культурного життя в Україні зокрема та світі загалом.

Автори також широко висвітлюють коло чинників, що мають вплив на розвиток української вокальної школи на різних етапах іiі існування, та роблять акцент на важливості вивчення історії національного вокалу. Крім того, аналіз доступних 3 цього питання наукових досліджень яскраво свідчить про неабияку зацікавленість 3 боку пред- ставників деяких наукових кіл щодо вивчення історії розвитку української пісенної та мовної культур невід'ємно від вивчення історії країни загалом. Адже тільки у контексті визнання наявності тісних зв'язків між різними аспектів та напрямами культурного життя країни можна вести мову про вивчення її культури та традицій у різних культурних сферах.

Мета статті полягає у визначенні різноманітних чинників розвитку української вокальної культури у іiі сучасному стані та у контексті іiі справжнього місця у культурному житті країни на поточний момент з огляду на багатовікову історію української пісні, іiі розвитку та удосконалення виконавчої майстерності представників української вокальної школи.

Виклад основного матеріалу. Розвиток української вокальної школи з огляду на її сучасний стан має тісний зв'язок із загальною історією розвитку української музичної культури та культури нації загалом. Українське народне музичне мистецтво формувалося протягом багатьох століть та має тісний зв'язок із культурою та традиціями народів, що проживали на суміжних територіях. Пісенна культура України представлена у скарбниці світової музичної культури різноманітними творами, що належать до вокального та інструментального жанрів. Ї̈̈ складовими особливостями можна вважати неповторну мелодійність звучання та використання у пісенній та інструментальній структурах творчої композиції запозичених мотивів, характерних для інших, сумісних 3 українською, пісенних та музичних культур (Мелякина, 2010: 332).

Серед головних питань сольного народно-співочого виконавства на сучасному етапі розвитку $\epsilon$ питання формування репертуару виконавця народної пісні. На сучасній естраді чимало вокалістів, які використовують у своїй творчості стандартні набори популярних пісень та дуже неохоче розширюють і збагачують свій сценічний пісенний репертуар, що є суттєвою перешкодою для формування яскравої виконавчої індивідуальності. Практика нерідко демонструє відсутність у сучасних виконавців народної пісні смаку, творчого мислення, загальної культури і нерозуміння ними специфіки народної піснетворчості.

Проблема синтезу музики, слова й хореографії також вельми актуальна для сучасного соліста (Муттер, 2017: 49). У зв'язку з цим виникають питання, як співати, залишаючись сучасним та зрозумілим, органічно поєднувати самобутність виконання 3 глибиною змісту, виробляти гідне враження на слухача. Саме тому й виникає 
потреба формувати репертуар з урахуванням усіх перелічених чинників, особливо коли йдеться про формування репертуару співака народних українських пісень, що виступає якісним продовжувачем та розповсюджувачем традицій української вокальної школи на сучасному етапі розвитку української та світової пісенних культур.

Найбільший вплив на цей процес має чинити освіта, особливо у контексті формування належних навичок складання репертуарів певного стилістичного напряму (Федоренко, 2010: 270). Перед музичними педагогами стоїть найважливіше завдання - не лише прищепити майбутньому вокалістові навички правильної вокалізації, дихання, з'єднання регістрів, діалектної вимови, а й виховати освічену та музично грамотну людину, орієнтовану у сучасному народно-пісенному й авторському репертуарі, яка вміє самостійно відбирати й інтерпретувати твори для свого типу голосу, складати концертні програми, має здатність аналізувати та піддавати критичному аналізу особливості власного виконавчого стилю (Муттер, 2017: 49).

3 такої точки зору слід звернути належну увагу на питання висвітлення самого поняття «вокальна школа» у контексті підготовки майстрів вокального жанру у сучасних умовах. В історичних дослідженнях зазвичай неявно приймається двояке розуміння поняття «вокальна школа», яке нерідко призводить до невизначеності. В основі єдиної думки лежить принцип територіальності, згідно 3 яким упорядкування матеріалу та його розгляд відбувається в межах деякої території. Основу іншого розуміння вокальної школи становить етнічна ментальність характеристик, які часто називають «духом», «душею» певного народу. Найчастіше ця двоїстість розуміння вокальної школи зливається в монолітне ціле, сприймається як щось саме собою зрозуміле й виступає перевіреним, ефективним засобом упорядкування i осмислення культурно-історичного матеріалу.

Однак у процесі етногенезу в межах деякої території, коли розпадаються старі етнічні освіти, виникають нові, стикаються різні етноси (або культури) в результаті завоювань і т.п., спостерігається двояке розуміння вокальної школи. Звідси нерідко перебільшення одного з аспектів поняття «вокальна школа» призводить до протиріч та парадоксів. Так, серед українських істориків, культурологів переважає територіальний підхід у визначенні початку й генезису української вокальної школи. Ті, хто заперечують взагалі існування української вокальної школи, посилаючись на відсутність самостійної високої української культури, неминуче стикаються з труднощами ідентифікації того культурно-історичного процесу, який мав місце саме в цьому регіоні (Белов, 2009: 67-68).

Можна 3 упевненістю стверджувати, що питання семантичної подвійності поняття «школа» загалом та «вокальна школа» зокрема носять універсальний характер. Усвідомлення цієї обставини знімає безліч дискусій, коли сторони, що беруть участь у суперечці, спираючись на різні аспекти розуміння школи, міркують про різне ставлення до проблеми. При цьому позиції кожної зі сторін мають достатні підстави. На жаль, проблема виникнення української національної вокальної школи ще не отримала належного теоретичного та методологічного осмислення в культурології. Найчастіше обмежуються розглядом послідовності шарів і, таким чином, неявно прийнятий як вихідний позакультурологічний принцип територіальності фактично елімінує проблему початку виникнення певної школи. Тому в культурологічній літературі проблема початку виникнення шкіл не отримала належної уваги або формулюється та вирішується в досить абстрактній формі (Корнієнко, 2014: 6). Звісно ж, виділення єдиних, універсальних критеріїв навряд чи можливе та доцільне через неоднорідність культурно-історичного процесу (Белов, 2009: 69).

Розвиток української вокальної школи на сучасному етапі має під собою підгрунтя, формування якого відбувалося ще протягом історичного розвитку культури Росії дореволюційного періоду. У Росії протягом століть склалися найбільші музикознавчі та виконавські школи - інструментальні, хорові, вокальні (Бояркин, 2009: 369). Традиції російської та української музичної освіти дістали визнання в усьому світі. Однак за останні десятиліття, внаслідок докорінних змін у соціальному та культурному житті країн колишнього Радянського Союзу, в музичній педагогіці намітилася тенденція в бік європейських концепцій музичної освіти. Мало місце масштабне витіснення багатьох ідей, теорій та навчальних і наукових методик, що можна вважати складниками 3 точки зору національної музичної освіти протягом багатьох століть (Косовцов, 2018: 53). Це робить свій негативний вплив на рівень підготовки фахівців, у тому числі теперішніх українських музикантів-вокалістів, а також виконавців українських народних пісень.

Водночас значення системи підготовки вокалістів у системі української вокальної школи зростає, оскільки суттєво зростає значення інтеграції основ культурної традиції із завданнями сучасного розвитку культури загалом та вокальної культури зокрема. У цьому аспекті важливою особливістю освіти, в тому числі й української 
вокальної освіти у контексті діяльності української вокальної школи, $є$ трансляція культурної традиції у вимірі часу крізь низку поколінь. У зв'язку з цим актуальним завданням $є$ звернення до витоків українських традицій культури та освіти загалом і вокальної культури та освіти зокрема. Фундаментального дослідження потребують традиційні основи вокальної освіти, що склалися у процесі історичного розвитку культури та традицій українського народу.

Національна українська школа співу формується як $з$ вокально-технологічних принципів, так і з особливості психологічного складу української нації, витоків їі музичної культури, особливостей історичного розвитку української пісенної майстерності. Простіше кажучи, добре співаючи, співаки користуються подібними вокальними техніками. Історично російська й українська вокальні школи у сучасних умовах беруть свій початок 3 творчості М. І. Глинки - першого російського композитора-класика i вокального педагога. Однак потрібно зазначити, що спроби організації музичного театру в Україні були ще у середині XVII ст., а в 1735 році була запрошена на постійну роботу італійська оперна трупа на чолі 3 Ф. Арайя - композитором та диригентом. До моменту проникнення італійської оперної музики в Росію Італія вже переживала так званий другий період епохи бельканто - періоду віртуозної оперної техніки (Белов, 2009: 72).

У сучасних умовах, що сформувалися, немає чіткого розподілу на окремі вокальні школи, будь то італійська, російська або німецька чи українська. Фахівці можуть вести мову скоріше про погане чи якісне виконання. Історично «бельканто» має трактування як стиль виконання, але не як техніка співу. Вимоги до техніки співаків зараз інтернаціональні: «близьке» формування звуку, тонке змикання, низька опора на дихання, рівне звуковедення, абсолютно позбавлене будь-якого виду форсування. Головна відмінність навчання вокалу в Італії та Україні полягає в тому, що італійці ведуть підготовку власних зірок оперного співу у приватних школах, тому що вважають голос «штучним товаром», що потребує особливої огранки. Таке можливе лише за умови щогодинної турботи та уваги, чого немає можливості отримати в умовах навчання у консерваторії.

Таким чином, вокальна школа - основа основ правильного та якісного співу. Українська вокальна школа на сучасному етапі свого розвитку, безумовно, істотно відрізняється від інших вокальних шкіл, має свої характерні риси, базується на історично сформованих традиціях цер- ковного і народного співу, відома і знаменита на багатьох континентах. Ї̈і численні представники виконавці та педагоги в різних точках Земної кулі поширюють свої знання та досвід. Безумовно, це $\epsilon$ характерною ознакою поваги до вітчизняної школи вокалу та свідчить про неабияке визнання досягнень української вокальної школи на сучасному етапі іiї існування та може вважатися запорукою іiі подальшого розвитку та вдосконалення (Антоненко, 2013: 14-15).

Висновки. Дослідження певних чинників, що мають значення 3 точки зору оцінки розвитку української вокальної школи в умовах реалій сучасного розвитку культури в Україні свідчить про складний та багатогранний шлях мистецтва співу в Україні. Загалом для сучасного етапу розвитку національного самопізнання можна вважати характерним зростання інтересу до питань культурної спадщини загалом, невід'ємною частиною якої виступає комплекс питань щодо сучасного стану розвитку школи вокалу в Україні. Це стало закономірним наслідком розвитку національних культур, що вступили у складний період нових соціально-політичних реалій, процесів глобалізації, що викликали різноманітні форми функціонування етнічних традицій у побуті народів, форм їх використання у сучасній художній творчості.

Розвиток української вокальної школи у контексті сучасного стану національної культури та традицій українського народу $є$ наслідком взаємопроникнення та взаємозбагачення багатьох культур, що мали суттєвий вплив на українську

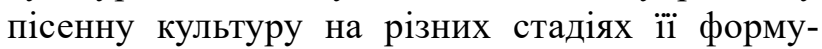
вання. У цьому контексті можна згадати культуру італійського оперного співу, російську школу вокального мистецтва або школу угорських або румунських хорових традицій. Саме гармонічне поєднання різних складників, що мали вплив на українську вокальну школу на всіх етапах ії розвитку, багато в чому сформувало iї теперішне становище та місце, яке нині посідає українська вокальна школа у сучасному музичному світі. Як наглядно демонструє багаторічна практика, що успішно зарекомендувала себе у світовій педагогіці як одна з високоефективних освітніх систем, підготовка фахівців, що склалася в сучасній Україні за багатьма музично-теоретичними та виконавськими напрямами, виявилася не досить ефективною для спеціальностей, в яких роль регіонально-етнічного компонента найбільш відповідальна та суттєва.

Це свідчить про те, що завдання якісної підготовки фахівців музичних спеціальностей загалом та вокального жанру зокрема не може бути 
в повному обсязі якісно виконане за умов нинішнього стану системи вищої музичної освіти в Україні. Ця ситуація зумовлюе необхідність постановки та якісного вирішення широкого кола питань щодо удосконалення діяльності школи вокальної підготовки в Україні у сучасних умовах, а також свідчить про наявність певних ресурсів покращення рівня музичної освіти в Україні загалом. Адже навіть за умов наявності багатьох проблем у сучасній системі підготовки українських музикантів представники нашої країни щорічно посідають призові місця на всесвітньо відомих конкурсах виконавчої майстерності. Це стосується не лише учнів-інструменталістів, а й представників вітчизняної вокальної школи. Наявність можливостей для покращення результатів діяльності української вокальної школи у сучасних умовах $\epsilon$ запорукою iii подальшого розвитку та сприяє зміцненню культури та музичних традицій української нації загалом.

\section{СПИСОК ВИКОРИСТАНИХ ДЖЕРЕЛ}

1. Антоненко А. Н. Творчество композиторов Запорожского края в контексте развития хоровой культуры региона (конец XX - начало XXI века). Культурная жизнь Юга России. 2013. № 4 (51). С. 13-17.

2. Белов Е. Е. Понятие «вокальная школа» в историко-культурологическом анализе. Социально-гуманитарные знания. 2009. № 6. С. 67-76.

3. Бояркин Н. И. О некоторых концептуальных основах подготовки специалистов по народно-певческим направлениям. Инженерные технологии и системы. 2009. № 2. С. 366-370.

4. Ковбасюк А. М. Вплив фонетики української мови на вокальне виконання. Манускрипт. 2016. № 4 (66). C. $78-81$.

5. Косовцов Н. Е. Классическое вокальное образование в России в XIX веке. Теоретические основы и традиции. Ценности и смысльы. 2018. № 7, С. 45-65.

6. Корнієнко В. Р. Поєднання української народної та естрадної пісні, синтезуючи з танцем та сценічним образом, - стилізація української народної пісні. APRIORI. Серія: Гуманітарні науки. 2014. № 4. С. 1-8.

7. Мелякина Е. М. Становление и развитие народно-певческой культуры в регионе. Регионология. 2010. № 6. C. 331-337.

8. Муттер Н. В. Формирование репертуара народного певца. Южно-Российский музыкальный альманах. 2017. № 4. C. 49-54.

9. Щербинина С. В. Вокально-исполнительское мастерство народных певцов. Педагогическое образование в России. 2013. № 5. С. 163-168.

10. Федоренко А. В. Этноестрада в современной культуре. Царскосельские чтения. 2010. № 5. С. 267-272.

\section{REFERENCES}

1. Antonenko A. N. Tvorchestvo kompozitorov Zaporozhskogo kraya $\mathrm{v}$ kontekste razvitiya horovoy kulturyi regiona (konets XX - nachalo XXI veka) [Creativity of the composers of the Zaporizhzhya region in the context of the development of the choral culture of the region (late XX - early XXI century)]. Kulturnaya zhizn Yuga Rossii, 2013, No. 4 (51), pp. 13-17 [in Russian].

2. Belov E. E. Ponyatie "vokalnaya shkola" v istoriko-kulturologicheskom analize [The concept of "vocal school" in the historical and cultural analysis]. Sotsialno-gumanitarnyie znaniya, 2009, No. 6, pp. 67-76 [in Russian].

3. Boyarkin N. I. O nekotoryih kontseptualnyih osnovah podgotovki spetsialistov po narodno-pevcheskim napravleniyam [About some conceptual foundations of training specialists in folk singing directions]. Inzhenernyie tehnologii $i$ sistemyi, 2009, No. 2, pp. 366-370 [in Russian].

4. Kovbasiuk A. M. Vplyv fonetyky ukrainskoi movy na vokalne vykonannia [Injection of the phonetics of the Ukrainian language on the vocal performance]. Manuskrypt, 2016, No. 4 (66), pp. $78-81$ [in Ukrainian].

5. Kosovtsov N. E. Klassicheskoe vokalnoye obrazovanie $\mathrm{v}$ Rossii $\mathrm{v}$ XIX veke. Teoreticheskie osnovyi i traditsii [Classical vocal education in Russia in the 19th century. Theoretical foundations and traditions]. Tsennosti $i$ smyisly, 2018, No. 7, pp. 45-65 [in Russian].

6. Korniienko V. R. Poiednannia ukrainskoi narodnoi ta estradnoi pisni, syntezuiuchy z tantsem ta stsenichnym obrazom, - stylizatsiia ukrainskoi narodnoi pisni [Presentation of the Ukrainian folk song, synthesizing with dance and in a scenic way, - stylization of the Ukrainian folk song]. APRIORI. Seriia: Humanitarni nauky, 2014, No. 4, pp. 1-8 [in Ukrainian].

7. Melyakina E. M. Stanovlenie i razvitie narodno-pevcheskoy kulturyi v regione [Formation and development of folk singing culture in the region]. Regionologiya, 2010, No. 6, pp. 331-337 [in Russian].

8. Mutter N. V. Formirovanie repertuara narodnogo pevtsa [Formation of the repertoire of the folk singer]. YuzhnoRossiyskiy muzyikalnyiy almanah, 2017, No. 4, pp. 49-54 [in Russian].

9. Scherbinina S. V. Vokalno-ispolnitelskoe masterstvo narodnyih pevtsov [Vocal and performing skills of folk singers]. Pedagogicheskoe obrazovanie v Rossii, 2013, No. 5, pp. 163-168 [in Russian].

10. Fedorenko A. V. Etnoestrada v sovremennoy culture [Ethnoestrada in modern culture]. Tsarskoselskie chteniya, 2010, No. 5, pp. 267-272 [in Russian]. 